\title{
Restrictive Foreign Sovereign Immunity in the United Kingdom (UK): A Welcome Development in International Commercial Transactions
}

\author{
Alhassan Salifu Bawah (i) \\ Business School, University of Education, Winneba, Ghana \\ Email: saliba101@yahoo.com
}

How to cite this paper: Bawah, A. S. (2019). Restrictive Foreign Sovereign Immunity in the United Kingdom (UK): A Welcome Development in International Commercial Transactions. Beijing Law Review, 10, 168-177.

https://doi.org/10.4236/blr.2019.101010

Received: January 28, 2019

Accepted: March 1, 2019

Published: March 4, 2019

Copyright () 2019 by author(s) and Scientific Research Publishing Inc. This work is licensed under the Creative Commons Attribution International License (CC BY 4.0).

http://creativecommons.org/licenses/by/4.0/

\begin{abstract}
The doctrine of absolute foreign State immunity to a great degree, appeared to stifle commercial transactions between contracting State parties and the private sector. Statute and earlier case law both attest to the absolute immunity of foreign States from the English courts' jurisdiction. However, latter dicta of the English courts under the UK State Immunity Act 1978 (SIA 1978), successfully made a distinction between instances where a State's actions were wholly of governmental character and some actions of the government that appeared commercial in nature, with basically features, similar to normal commercial transactions entered into by private individuals and companies. This paper, after a careful and painstaking overview of recent cases, concludes that the drift towards restrictive foreign State immunity by the English courts with respect to commercial transactions entered into by States, is a healthy development that carries the advantage of creating greater transparency, which in turn gives assurance to private individuals and companies that the State could be held liable for a breach of its commercial contractual obligations. Without this development, governments such as the Chinese government, which is basically operating as a "commercial/business conglomerate", can argue State immunity in disputes involving commercial transactions entered into between the Chinese government and the private sector. This research, would in no small way, encourage private individuals and companies to enter into commercial transactions with sovereign States without hesitation, safe in the knowledge that the UK courts, are ready and willing to hold contracting State parties in commercial transactions, accountable.
\end{abstract}

\section{Keywords}

State Immunity Act, Absolute State Immunity, Restrictive State Immunity, Commercial Transactions, Contracting State Parties, Foreign States, 
Jurisdiction, Foreign Sovereign Immunities Act, Recognition and Enforcement of Judgments

\section{Introduction}

This article will examine the concept of Sovereign Immunity vis-à-vis commercial transactions in contracts involving the private sector and contracting State parties in light of the provisions of the United Kingdom (UK) State Immunity Act 1978 (SIA 1978); discuss the essential ingredients needed to qualify a foreign State's transaction as commercial; proceed to take an in-depth look at the requirements for the enforcement of judgments against foreign States or State entities in the UK; and conclude that the drift of the English courts towards holding State parties accountable in respect of their contractual obligations under a commercial transaction, has created sanity in transactions involving the private sector and contracting State parties.

Section 1 captures the introduction and the drift of the English courts from absolute State immunity to restrictive State immunity; Section 2 proceeds to holistically examine the distinguishing features of a commercial transaction, in order to draw a clear distinction between transactions of purely commercial nature (which would ultimately bind a foreign State), from other governmental undertakings; Section 3 takes a look at the enforcement of judgments against foreign States and Central Banks in the UK; while Section 4 concludes the study.

\section{The Drift from Absolute Foreign State Immunity to Restrictive State Immunity}

\subsection{Absolute Foreign State Immunity}

The basic principle of the SIA 1978 is that a foreign State is immune from the jurisdiction of the English courts and effect is to be given to the immunity whether or not the State appears in the proceedings. ${ }^{1}$

Up to most part of the $20^{\text {th }}$ Century, foreign State immunity was seen to be absolute. Foreign States were accorded immunity in all activities, be it governmental or commercial.

In cases which fall within SIA 1978 section (s) 1, but not within any of the exceptions, the immunity was held by the UK Court of Appeal to be absolute and not subject to further exceptions on the ground that the conduct in question went contrary to international law, thus Al-Adsani $v$ Government of Kuwait. ${ }^{2}$ In this case, the court upheld the government's plea of State immunity in proceedings where the claimant alleged torture by government officials. A similar conclusion was reached by the United States Supreme Court with regards to the interpretation of the Foreign Sovereign Immunities Act 1976 in Argentine Repub${ }^{1}$ State Immunity Act 1978, s 1. ${ }^{2}$ [1996] 107 I. L. R. 536. 
lic $v$ Amerada Hess Shipping Corporation. ${ }^{3}$ This decision was followed by the United States Court of Appeal for the Ninth Circuit, perhaps with some reluctance, in Siderman de Blake $v$ Republic of Argentina, ${ }^{4}$ also a case of allegations of torture carried out by State officials.

\subsection{Restrictive Theory of Foreign State Immunity}

The increase in States' trading in the latter part of the $20^{\text {th }}$ Century, led a number of States including the UK, to develop the restrictive theory of foreign State immunity, resting upon a distinction between acts of purely governmental in character and acts of the government that had commercial transactions traits, which are scarcely any different from the activities of private individuals and companies. Under the restrictive theory, foreign States are immune in respect of acts of government but not in respect of commercial acts.

The House of Lords (now Supreme Court) decision in The I Congreso del Partido $^{5}$ and the Privy Council's decision in The Philippine Admiral, ${ }^{6}$ that a foreign government was not entitled to immunity in an action in rem against a ship used for trading purposes, and the Court of Appeal majority decision in Trendtex Trading Corporation $v$ Central Bank of Nigeria, ${ }^{7}$ that a State was not entitled to immunity in respect of commercial transactions, pointed towards a shift away from the doctrine of absolute foreign State immunity. The judgment of Lord Denning M. R. in Trendtex, was later described as marking the definitive absorption by the common law of the restrictive theory of sovereign immunity (McClean \& Beevers, 2009: p. 146). The restrictive doctrine of sovereign immunity was applied, both to actions in rem and in personam, under which a foreign State was entitled to immunity in respect of its governmental acts but not in respect of its commercial transactions.

The SIA 1978 which was designed partially to implement the 1972 European Convention on State Immunity embodied these common law developments on restrictive foreign State immunity in substance, in the form of exceptions provided for under sections (ss) 2 to 11 .

\section{Definition of Commercial Transactions}

Section 3 of SIA 1978 provides that: "A State is not immune in proceedings relating to a commercial transaction entered into by the State". Once the sovereign has descended from "his" throne and entered the marketplace, "he" has divested "himself of "his" sovereign status and is therefore no longer immune to the domestic jurisdiction of the English courts.

A commercial transaction is defined to include not only contracts for the supply of goods or services but also the provision of finance through loans, and

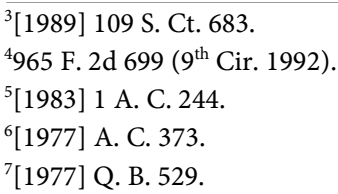


any guarantee or indemnity in respect of such transactions. It extends further to any transaction or activity (whether of a commercial, industrial, financial, professional or other similar character) into which a State enters or in which it engages otherwise than in the exercise of sovereign authority. It includes any obligation of the foreign State which by virtue of a contract, whether or not a commercial transaction falls to be performed in whole or in part in the UK. There must also be proceedings relating to a commercial transaction (Fawcett, Carruthers, \& North, 2008: p. 497).

The above wider definition of a "commercial transaction", has generated a lot of academic debate as to what actually constitute a commercial transaction in this modern era of dwindling and exhaustive natural resources which compels most States to diversify their sources of income in order to cope with the ever increasing demands of the general populace in terms of the provision of infrastructure, health, education, etc. This paper's position is that where a State or State entity descends into the commercial arena, there is no justification for allowing that State to avoid the economic costs of its actions. Emerging jurisprudence discussed below would spice up the debate as to the exact definition of a commercial transaction, which to some extent, is still not settled.

The development of this practice was in part due to the explosion in the growth of international trade and investment, which led to the recognition that there would otherwise exist an unfair balance of power if private litigants were denied a judicial remedy in situations where States (or Heads of State) engage in commercial activities outside of what would ordinarily be termed official governmental functions. The difficult question is, is a separate entity which is distinct from the executive organs of government of the foreign State and being capable of suing or being sued, entitled to immunity or not?

SIA 1978 provides that the separate entity is not immune, unless the proceedings relate to something done by the separate entity in the exercise of sovereign authority and the circumstances were such that the State would have been immune.

The House of Lords in Kuwait Airways Corporation v Iraqi Airways Co., ${ }^{8}$ held that the term "separate entity" refers to the common law concept of acta jure imperii, and that Iraqi Airways was so acting when it removed aircraft from Kuwait following the Iraqi invasion in 1990. The airline was closely involved with the State of Iraq in both the seizure and removal of the aircraft from Kuwait to Iraq.

Even though the seizure, removal, retention, and use of the aircraft, was done in consequence of a legislative decree vesting the aircraft in the airline, the House of Lords however held that Iraqi Airways was not immune.

In Orascom Telecom Holding SAE ${ }_{V}$ Chad, ${ }^{9}$ the claimant was attempting to enforce an International Chamber of Commerce (ICC) arbitration award by means of a third party debt order against bank accounts held by Chad with Citi${ }^{8}$ [1995] 1 WLR 1147. ${ }^{9}$ [2008] EWHC 1841 (Comm). 
bank in London. Chad had not satisfied the award and resisted enforcement on the grounds of State immunity. The Citibank accounts had been established as part of a Revenue Management Programme (RMP) agreed between the World Bank, European Investment Bank and Chad, under loans made to the State to construct an oil pipeline. The account structure in London was such that oil revenues payable to Chad could be channelled through London, thereby creating greater transparency and also ensuring repayment of the loans.

Burton $J$ held that the accounts were in use for commercial purposes. $\mathrm{He}$ found that moneys were only paid into the London account because it had been a condition of the RMP that they be held there. In other words, they were there for the purposes of a commercial transaction within the meaning of SIA s.3 (3). As such, the credit balance of the account was not immune from execution, and Orascom was entitled to a final third party debt order attaching it.

This decision goes further to blur the distinction as to what exactly constitute a commercial transaction from acts of the State that are purely in the exercise of sovereign authority. This is because the purpose of the loan from the World Bank was to construct a pipe line as part of laying down infrastructure for the development of the country which every responsible government has a duty to perform. This may be likened to the construction of a road to enable the efficient transportation of goods, or the payment of salaries of public sector employees to aid in the efficient running of government machinery, which are all acts of sovereign authority and the funds definitely has to come from somewhere. This paper is sceptical of this decision.

Another controversial decision with regards to what actually constitute a commercial transaction, is the decision of the UK Court of Appeal in Svenska Petroleum Exploration AB v Lithuania (No. 2). ${ }^{10}$

A contract between the parties contained several provisions, among them, the provision that: "GOVERNMENT and EPG hereby irrevocably waive all rights to sovereign immunity". EPG was at the material time a separate legal entity owned and controlled by the Government of Lithuania.

Despite the existence of the above provision, the Court of Appeal left open the question, whether a joint venture agreement between a State organisation and a private investor to exploit a commercial opportunity relating to the State's natural resources on a profit-sharing basis was to be regarded as a commercial transaction for the purposes of SIA 1978 s. 3 (3) (c) (Dicey, Morris, \& Collins, 2008: p. 37).

However, in Tsavliris Salvage (International) Ltd. v Grain Board of Iraq, which was also a venture between a State owned entity and a private company, mirroring Svenska, Gross J held that no State immunity existed. In essence, what the judge did was to justify the statement that where a State or State entity descends into the commercial arena, there is no justification in allowing that State to avoid the economic costs of its actions.

From the above, it can be clearly seen that the courts are not settled on the ${ }^{10}[2006]$ EWCA Civ 1529. 
precise definition of a commercial transaction. The enforcement of judgments falling under this exception is examined next.

\section{Enforcement of Judgments}

\subsection{Enforcement against Foreign States in the UK}

It is of paramount importance to state that a judgment is useless if it cannot be enforced. SIA 1978 s. 13 (2) (b) provides that: "The property of a State shall not be subject to any process of enforcement of a judgment or arbitration award, or in an action in rem, for its arrest, detention or sale". There are some exceptions to this principle, including waiver, which has to be made in writing by the State under SIA 1978 s. 13 (3).

The territory of enforcement is not also a straightforward business just as it is in the case of determining what actually amounts to a commercial transaction.

In AIC Ltd. v Federal Government of Nigeria, ${ }^{12}$ Stanley Burton J refused an order to enforce against a foreign State (Nigeria), in a judgment made by a court of that State (Nigeria). He held that the recognition and enforcement by the English courts of a foreign judgment given against a foreign State was an exercise of adjudicative jurisdiction within the immunity conferred by s.1 of the $S I A$ 1978. There being no applicable exception from such immunity in ss. 2-11, nor any provision for the registration of a foreign judgment given against a foreign State under the provisions of the Administration of Justice Act 1920 or the Foreign Judgments (Reciprocal Enforcement) Act 1933, the English court had no jurisdiction to enforce such a judgment given against Nigeria by one of its own courts, even though the transaction underlying the original judgment might be of a commercial nature.

This decision had its "twin brother" in the UK Court of Appeal holding in NML Capital Ltd. v Republic of Argentina, ${ }^{13}$ which was subsequently overturned on appeal to the Supreme Court.

In the $N M L$ case, the claimant, having obtained a judgment in its favour abroad, sought to enforce it in England and submitted that the foreign court's judgment was capable of being recognised and enforced in the UK by virtue of $s$. 31 of the Civil Jurisdiction and Judgment Act (CJJA) 1982, as the foreign court had jurisdiction over the defendant under sovereign immunity rules corresponding to those applicable in England.

The Court of Appeal held that CJJA 1982 s. 31 was enacted against the background of the SIA 1978 and did not introduce a new and comprehensive statutory framework for the recognition and enforcement in the UK courts, of judgments of foreign courts against foreign States independent of the SIA 1978.

However, the Supreme Court, in allowing the claimant's appeal held that the effect of s. 31 of the CJJA 1982 was to provide for the recognition in England of a foreign judgment against a State where there exists a connection between the ${ }^{11}$ [2008] EWHC 612 (Comm).

${ }^{12}$ [2003] EWHC 1357.

${ }^{13}$ [2011] UKSC 31 (SC). 
subject matter of that judgment and the forum State that is equivalent to one that would give rise to an exemption from immunity in the English courts' jurisdiction.

The Supreme Court went further to hold that a foreign judgment against a State within s. 31 of the CJJA 1982, is to be recognised and enforced by the English courts if the judgment would be so recognised and enforced if it had not been given against a State and the foreign court would have had jurisdiction in the matter if it had applied rules corresponding to those applicable to such matters in the UK in accordance with ss. 2 to 11 of the SIA 1978.

It is generally recognised that no principle of international law renders a particular State immune as regards proceedings brought in another State to enforce a judgment given in the court of a third State. In the UK Supreme Court minority's view, the immunity of the State depended to a greater extent on the nature of the underlying transaction that had given rise to the claim, and not upon the nature of the process by which it was sought to be enforced. And that the SIA 1978 had not expressly provided for or included a foreign judgment within an exception to immunity but it might have been reasonable to give the SIA 1978 an up to date meaning in tandem with developing circumstances as the courts had done in other cases.

In holding that a foreign judgment in the particular circumstances attracted immunity, the judge in the AIC V Nigeria case, had relied on SIA 1978 s. 9, since it expressly recognised an exception to immunity for arbitration agreements and further recognised that such a procedural stage might attract immunity. This argument however, was shown to be inconclusive as the prime purpose of the SIA 1978 s. 9 enactment, was to override the rule.

In Duff Development Co. Ltd. v Government of Kelantan, ${ }^{14}$ a second express waiver was required by the State at the enforcement stage for the removal of immunity. Stanley Burton J had favoured the narrower meaning, thus excluding a foreign judgment from coming within the exception to immunity in SIA 1978 s. 3 (1) as "relating to a commercial transaction", by reason that the s. 3 exception required a link between the defendant State's transaction and the UK jurisdiction. However, Lord Phillips and Lord Mance, in buttressing their holding with the Hansard, concluded that in the course of its enactment, the Bill had been amended to apply to all States. "No qualifications, and no jurisdictional links with the UK are required".

The truly decisive argument however, was the absence in 1978 when the $S I A$ came into force, of any procedure by which a defendant State outside the jurisdiction could be served in an action on a foreign judgment, even if there were assets in the jurisdiction to satisfy the judgment.

The Supreme Court's decision in $N M L$ is remarkable for its mixture of flexibility in procedural matters, coupled with the technicality of the majority's decision in its adoption of a conflicts lawyer's treatment of substantive law. Furthermore, unlike the European Convention on State Immunity and the US For${ }^{14}[1924]$ AC 797. 
eign Sovereign Immunity Act, no territorial link with the UK (Forum State), is required as a condition necessary for a transaction to come within the exception to immunity relating to commercial transactions in $S I A 1978$ s. 3.

\subsection{Enforcement of Foreign Judgments against Central Banks in the UK}

Enforcement against Central Banks of foreign States in the UK is very difficult if not impossible. This is as a result of the special treatment accorded Central Banks under SIA 1978 s. 14 (4), which provides that: “The Central Banks' property is immune from execution and its property would only be liable for execution if it waives this immunity in writing".

However, in Re Banco National de Cuba ${ }^{15}$ it was held that a Central Bank did not have the protection of State immunity under SIA 1978 in proceedings concerned with an alleged transfer of shares at an undervalue, in circumstances where the transaction in question had not taken place pursuant to any legislative or executive direction but had been a purely commercial exercise (contrast this with Kuwait Airways as discussed earlier). This decision against the Central Bank of Cuba, may be explained on the basis that there appeared to be some form of corruption in the share transfer.

In contrast to the above decision, in AIG Capital Partners Inc. v Kazakhstan, ${ }^{16}$ it was held that the words "property of a State's Central Bank or other monetary authority" within SIA 1978 s. 14 (4) meant any asset in which the Central Bank had some kind of property interest irrespective of the capacity in which the Central Bank held the assets or the purpose for which the assets were held; therefore, even where it was unclear what the nature of the national bank's right was, the assets concerned were still immune from the enforcement process.

This paper is of the opinion that while as a matter of UK law, Aikens J's judgment in the $A I G$ case appears impeccable, the ordinary mortal will have very little sympathy for AIG and TREC whose project in Kazakhstan was expropriated in harsh circumstances without payment of the compensation to which they were entitled under the provisions of the US/Kazakh BIT and international law. It is a trite comment that harsh circumstances can lead to bad law and, as the judge made it clear in the details of his judgment, that "a Pandora's Box could have been opened by chipping away at the immunity possessed by a Central Bank".

In Svenska, as already examined above, the waiver of all rights of sovereign immunity clauses inserted in the agreement, was distinguished from the earlier decision in A Company Ltd. $v$ Republic of $X,{ }^{17}$ by Gloster J, where it was held that the contract also contained an express choice of English law and an express submission to the jurisdiction of the English courts, whereas Svenska had no such provision.

SIA 1978 s. 13 (3) to some extent, countenances the possibility that where ${ }^{15}$ [2001] 1 W. L. R 2039.

${ }^{16}$ [2005] EWHC 2239 (Comm). 
there is a waiver, the judgment can be enforced against non-commercial property. In effect, that provision would be redundant if a judgment can only be enforced against commercial property, because the claimant would simply rely on SIA 1978 s. 13 (4). Furthermore, under SIA 1978, the issue of waiver is analytically distinct from the issue of commercial purposes and the issue is whether simply the requirements of SIA 1978 s. 13 (3) are met, not whether the property against which enforcement is sought is used for commercial purposes.

In Servaas Inc. $v$ Rafidain Bank, ${ }^{18}$ an application for a third party debt order over a future distribution to be made to the Republic of Iraq in respect of certain assets had to be dismissed because the assets were not at the material time being used for commercial purposes and were therefore immune from execution under the SIA 1978 s. 13 (2) (b).

Private individuals and companies ought to be extra cautious when entering into commercial transactions with Central Banks, since enforcement against Central Banks, is highly unlikely in case a dispute arises.

\section{Observations and Conclusion}

The doctrine of State immunity is not static, and has undergone enormous changes in the last hundred years. No longer is State immunity seen as an absolute doctrine, particularly in the area of what can broadly be described as commercial activity. This was succinctly put by Lord Wilberforce in The I Congreso that: "... to require a State to answer a claim based on such transaction does not involve a challenge or inquiry into any act of sovereignty or governmental act of that State. It is, in accepted phrases, neither a threat to the dignity of that State nor any interference with its sovereign functions".

A State should be held to account for its actions when it enters into any form of commercial transaction with private individuals or companies. This will set the stage for States entering into commercial transactions not to wilfully disregard their contractual obligations, but rather take conscious steps towards honouring their obligations, bearing in mind the consequences of a breach of contract. This would in turn promote the efficient functioning of commerce and industry. However, individuals and companies, may have to be extra careful when entering into commercial transactions with Central Banks, since Central Banks still have the benefit of absolute foreign sovereign immunity under SIA 1978.

The world has been described as a global village by a section of the wider public, and it is not far-fetched to submit that the restrictive immunity approach adopted by the English courts in cases relating to commercial transactions is a catalyst that is likely to propel the economy of the "global village", to progress to the status of a "global town", and subsequently attain the status of a "global city" in the not too distant future.

Hakeem Seriki and Mark Beeley, commenting on the decision in Svenska in ${ }^{17}$ [1990] 2 Lloyd's Rep. 520.

${ }^{18}$ [2010] EWHC 3287 (Ch). 
an article titled: "Res Judicata: Recent Developments in Arbitration" which this paper agrees with, stated that the court has "... confirmed that where a State descends into the commercial arena, it will not be able to avoid its contractual obligations by simply pleading immunity, especially where the State is to derive a benefit under the contract" (Seriki \& Beevers, 2005: pp. 111-116).

\section{Conflicts of Interest}

The author declares no conflicts of interest regarding the publication of this paper.

\section{References}

Dicey, Morris, \& Collins (2008). The Conflict of Laws (14 ${ }^{\text {th }}$ Edition). London: Sweet \& Maxwell.

Fawcett, J. J., Carruthers, J. M., \& North, P. (2008). Private International Law (14 ${ }^{\text {th }}$ Edition). Oxford: Oxford University Press.

McClean, D., \& Beevers, K. (2009). The Conflict of Laws ( $7^{\text {th }}$ Edition). London: Sweet \& Maxwell.

Seriki, H., \& Beeley, M. (2005). Res Judicata: Recent Developments in Arbitration. International Arbitration Law Review, 111-116. 